Peter Karl Fleissner:

\title{
Opportunities of Change: An Economist's Perspective
}

\begin{abstract}
:
As contemporary scientific images of the economy by mainstream economists neglect historical changes, a method is needed to deal with the opportunities and possibilities of qualitative change, in particular in a period of evident crises. This paper sketches a methodology of reflecting the economy as an evolutionary/revolutionary process. There are two main reasons for that: The first is that scholars should think of reality in a more appropriate way, taking the fact into account that qualitative changes of the type of the economic reproduction process happened in the past and there is no reason that they will not also happen in future, the second, that new political movements demand a better life for all, not only for one per cent of the people.
\end{abstract}

\section{Agenda:}

Introduction

Use values

Commodity Production. 180

Competitive Capitalism 180

Finance Capitalism.

State Monopoly Capitalism and its Alternatives......

Finance Market Capitalism driven by Information Society

A democratic turn? 185

Concluding remarks

\section{Author:}

Prof. DI. Dr. Peter K. Fleissner:

- Jakschgasse 12/3, 1140 Vienna, Austria

- 淄 + 43 - 676 - 9308 906, $₫$ fleissner@arrakis.es,

- $\quad$ http://peter.fleissner.org/homepage/default.htm

- Relevant publications:

- Kämpfe um Land. Gutes Leben im post-fossilen Zeitalter (Fighting for Soil - A good life in post-fossile age). Andreas Exner, Peter Fleissner, Lukas Kranzl, Werner Zittel (Eds.). Wien: Mandelbaum Verlag, Reihe kritik und utopia 2011, 256 p.

- Does Europe develop towards socialism? A personal comment from the year 2025 In: International Critical Thought, 2011, 1:2, pp. 229-234. 
- From the Appearance of the Economy to Its Essence and Back: Methodological Preconditions on How to Analyze Crises In: World Review of Political Economy. 2010, Vol 1 Nr 3 Fall. Pluto Press, pp. 388-406.

- BruchStücke. Kritische Ansätze zu Politik und Ökonomie im globalisierten Kapitalismus. Materialien zur Ringvorlesung Sommersemester 2008 an der Universität Wien (FragMents - Critical Approaches on Politics and Economy in Globalized Capitalism). Peter Fleissner and Natascha Wanek (Eds.). Berlin: trafo Verlag Dr. Weist 2009, 392 p.

- Digitale Medien - neue Möglichkeiten für Demokratie und Partizipation? (Digital Media - New Potential for Democracy and Participation) Peter Fleissner and Vicente Romano (Eds.). Berlin: trafo Verlag Dr. Weist series: network - cultural diversity and new media, vol 7. 2007, 244 p. 


\section{Introduction}

The textbooks of the Anglo-Saxon world present the economy as interplay of utility- or profit-maximizing individuals. Usually they neglect its social and historical character. But seen with Marx's eyes the economy is basically an exercise in mutuality. People are producing for other people and getting something back in exchange. This relationship is described with the concept of value in its twofold form, as use value and exchange value. Competition between private producers in the market is a precondition to establish exchange value. It is the concept of "commodity" where both aspects of value are integrated. The market price we observe is a (sometimes modified) expression of the exchange value of a commodity in money terms. Money represents a general equivalent of social necessary labour (although in a different dimension, in monetary units instead of labour time). From here price - as we observe it empirically - can be interpreted as expression of the basic reciprocity between human beings, based on mutuality, of a fundamental interdependence of people although anonymously connected via markets where they sell and buy their products of work. As we will see later any long-term exclusion of people or any massive interruption of reciprocity drives the economy into crisis. Economic sustainability - implying the decent survival for all - is no longer granted.

Marx proposed to start the reconstruction of the economy on the level of essence, on a rather abstract level. Otherwise, we could not see the basic relationships within people. Marx kept up Adam Smith's idea that there is a basic relation of wealth to human labour. This reference keeps the link between the economy and the work of human beings, which is cut in mainstream economics.

The final goal of this investigation should be an enriched model of contemporary capitalism where the various steps of development can still be seen, but are no longer the dominant ones. The new layers influence the former ones and shed light of specific colour on them.

To illustrate this idea one can take Marx himself by example. In Volume 1 of "Das Kapital" he analysed in detail the various forms of value and established the methodological basis of the production process of capital with the commodity as its basic element. In the first 150 pages he introduced the measure of value by social necessary labour needed for the production of a commodity, which in fact would mean an economy of competitive small commodity producers working with their own means of production and without wage labour. He assumed competitive commodity markets, but no capitalist production. Later on he introduced the notion of fixed and variable capital, but we have to wait for Volume 2 where we find Engels selection of Marx's notes on the socalled transformation problem, which describes the modification of values under the influence of capitalist competition. Marx was first in discovering this modification process, of which Adam Smith was not yet aware. As idealized result of the transformation labour values are rescaled into prices of production. Their quantitative result is the sum of cost price expanded by the rate of profit, while the rates of profit in each sector of the economy are equalized and are also equal to the average rate. So we see on the methodological level that Marx was aware of the influence of capitalist competition - a new feature added to the former description has on the quantitative expression of value.

More recent investigations ${ }^{1}$ based on stochastic processes and random variables show theoretically and empirically that the rates of profit in an economy do not converge towards the average rate as Marx has thought, but keep up to be different according to a power distribution.

Nevertheless, Marx's prices of production represent idealized equilibrium prices under capitalist competition, which might be used to compare them with actual prices.

1 Farjoun, Emmanuel and Moshé Machover: Laws of Chaos: a probabilistic approach to political economy. 

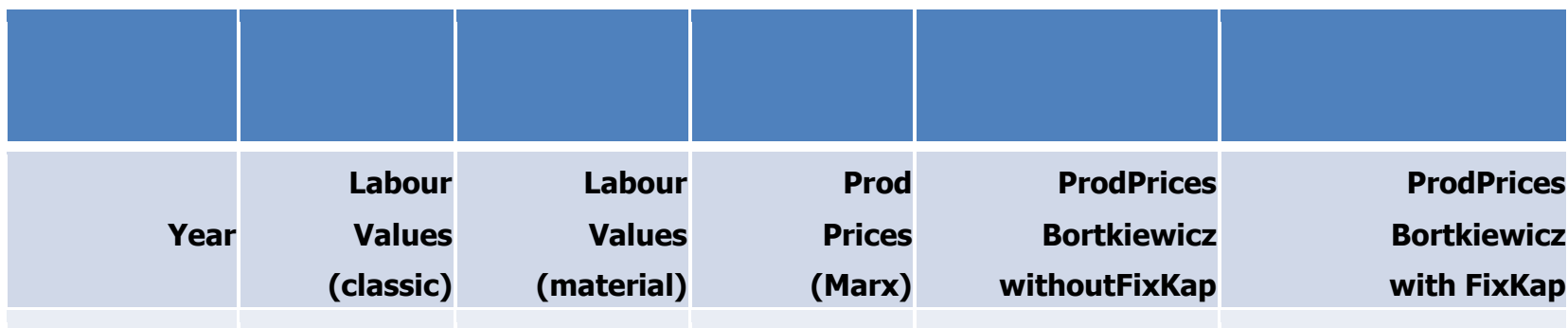

$\begin{array}{rrr}\text { Labour } & \text { Labour } & \text { Prod } \\ \text { Values } & \text { Values } & \text { Prices } \\ \text { classic) } & \text { (material) } & (\text { Marx })\end{array}$

ProdPrices
Bortkiewicz
withoutFixKap

ProdPrices

2006

$$
0.819
$$

0.710

0.832

0.941

Bortkiewicz

with FixKap

2003

0.883

0.802

0.901

0.952

Table 1: Correlations between observed prices, labour values and prices of production for Austria 2003 and $2006^{2}$

What can we learn from this example? By adding capitalist competition to an economy of small commodityproducers changes of the former prices are induced. Table 1 shows the results of the correlations between actual prices and ideal prices in the Austrian economy with 57 branches of production computed by various methods for the years 2003 and 2006. One can see that production prices show a slightly higher correlation with observed data than labour values.

In physics we have a nice example to illustrate this approach. Galileo Galilei has shown that gravitation accelerates all objects at the same rate, but if we test this proposition empirically, we find that a feather and a metal sphere will fall down with different speed. To explain the real movements of the feather we have to add further laws, like aerodynamics or theories of friction etc. We use a similar methodological framework and apply it to an existing economy.

It is seductive to repeat the evolutionary stages of development of the object in history by the steps of the research process. But this is not always possible. Historical developments interfere with changes of the logical structure of the object. In a book review on Marx's "Critique of Political Economy" in 1859 Engels interpreted Marx's analysis of capitalistic development as a logical analysis, which is "in fact nothing else as the historic development, without historic forms and disturbing contingencies." It is "a corrected mirror image, but corrected by laws, which are provided by history itself." ${ }^{3}$ Contemporary scholars prefer to speak of a logic-systematic approach instead of an image of historical development. We will follow this interpretation.

2 The differences in the computation of labour values stem from different assumptions about the role of services, in the first case as value producing, in the second without adding to the surplus product.

3 „Die Kritik der Ökonomie, selbst nach gewonnener Methode, konnte noch auf zweierlei Weise angelegt werden: historisch oder logisch. Da in der Geschichte, wie in ihrer literarischen Abspiegelung, die Entwicklung im ganzen und großen auch von den einfachsten zu den komplizierteren Verhältnissen fortgeht, so gab die literargeschichtliche Entwicklung der politischen Ökonomie einen natürlichen Leitfaden, an den die Kritik anknüpfen konnte, und im ganzen und großen würden die ökonomischen Kategorien dabei in derselben Reihenfolge erscheinen wie in der logischen Entwicklung. Diese Form hat scheinbar den Vorzug größerer Klarheit, da ja die wirkliche Entwicklung verfolgt wird, in der Tat aber würde sie dadurch höchstens populärer werden. Die Geschichte geht oft sprungweise und im Zickzack und müßte hierbei überall verfolgt werden, wodurch nicht nur viel Material von geringer Wichtigkeit aufgenommen, sondern auch der Gedankengang oft unterbrochen werden müßte; zudem ließe sich die Geschichte der Ökonomie nicht schreiben ohne die der bürgerlichen Gesellschaft, und damit würde die Arbeit unendlich, da alle Vorarbeiten fehlen. Die logische Behandlungsweise war also allein am Platz. Diese aber ist in der Tat nichts andres als die historische, nur entkleidet der historischen Form und der störenden Zufälligkeiten. Womit diese Geschichte anfängt, damit muß der Gedankengang ebenfalls anfangen, und sein weiterer Fortgang wird nichts sein als das Spiegelbild, in abstrakter und theoretisch konsequenter Form, des historischen Verlaufs; ein korrigiertes Spiegelbild, aber korrigiert nach Gesetzen, die der wirkliche geschichtliche Verlauf selbst an die Hand gibt, indem jedes Moment auf dem Entwicklungspunkt seiner vollen Reife, seiner Klassizität betrachtet werden kann." Marx, Karl and Friedrich Engels: Zur Kritik der Politischen Ökonomie [Rezension]. 468-477, $474 / 475$. 


\section{How to reconstruct the economy}

To keep pace with the changes in economic history in the last century we cannot stop at Marx' enlightening insights he wrote down in Das Kapital. We have to include additional features to make his description of the economy more realistic. For good reasons I follow Marx' method starting from very abstract layers and continue by including more recent developments inducing qualitative changes in the economy. Figure 1 illustrates the idea of a multi-level construction of the economy. It should be read from the bottom (most abstract) to the top (least abstract).

\section{Use values}

Layer 1 (see lower left corner of fig. 1) represents the material/energy basis of any economy in history. This basis is even necessary for any life on earth, plants or animal communities. The physical/energetic aspects of goods are important - given the chronic shortage of certain materials nowadays, peak oil, non-renewable resources, solid, liquid, gaseous or radioactive waste etc.

On the level of use-values we abstract from markets, from labour, from prices, from wages, from capital, from money, from power relations, from governance etc. We abstract from anything, social development and the interaction of people have added over history. On the other hand we see that layer 1 cannot represent any real economy in history, because any specific historic production was always connected with specific relations of production. Therefore, level 1 just shows the logical-systematic structure of the economic system.

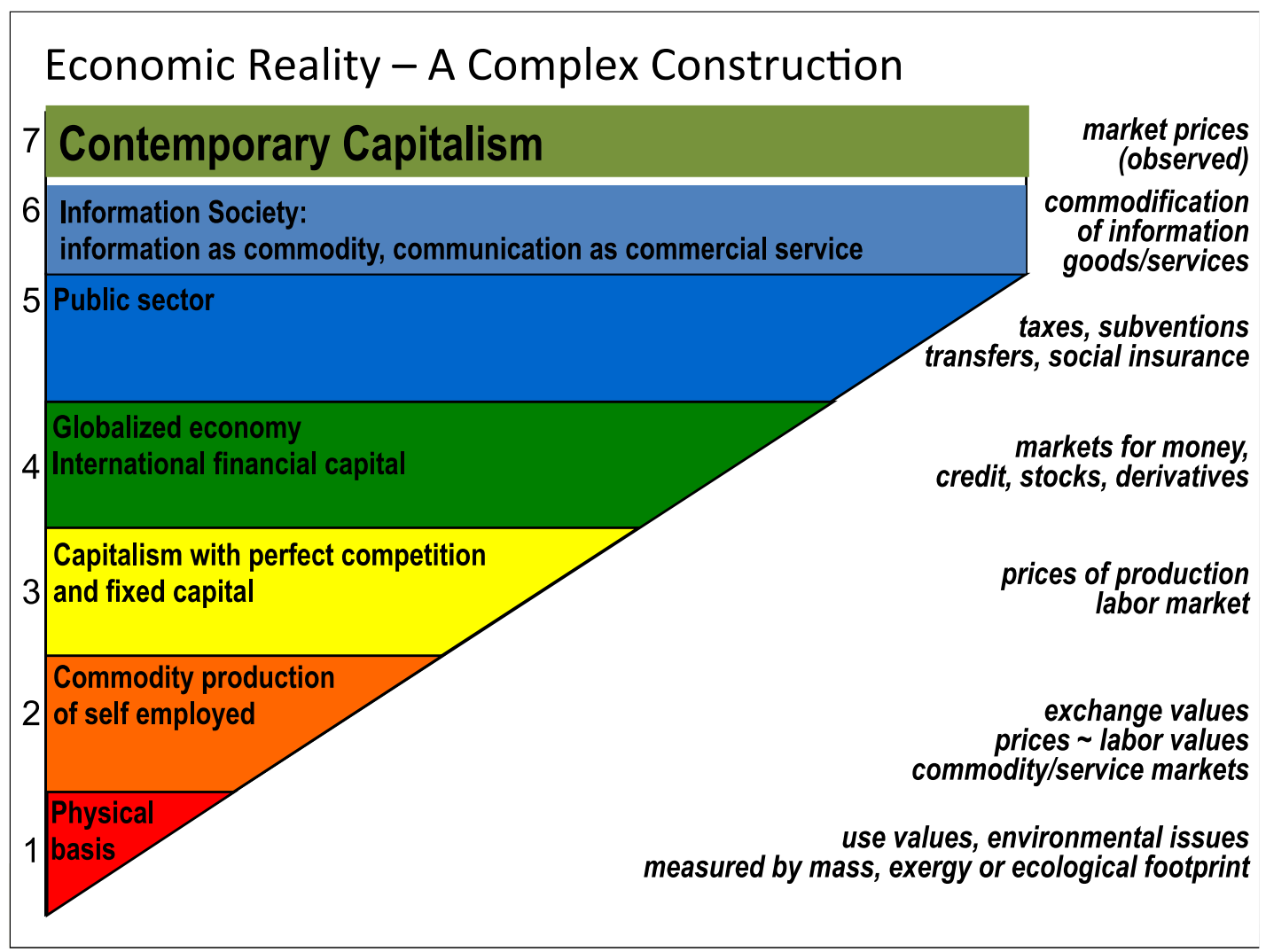

Figure 1: The reconstruction of the economy 


\section{Commodity Production}

What classical economists like Karl Marx in Das Kapital, volume one, and Adam Smith have added to goods is their origin (fig. 1, layer 2). Commodities are born out of work. The prices of goods are assumed to be proportional to socially necessary labour expended (exchange values). We interpret the first part of Das Kapital, volume 1, as a description of an economy where markets are established as a consequence of the division of labour. Competition is there and makes the individual contributions of work to the economy comparable to the social average.

Of course, the first layer is a necessary precondition for the second one. Without use-values no reproduction of human beings is possible. Layer 2 shows that without labour no use-value can be brought into existence.

Besides the static representation of the economy in figure 1 there is another way of graphical description based on feedback loops. From this perspective one can understand the dynamics of the second layer as the reproduction of the life of working people (see fig. 2). By selling their products on the market they get money back and are able to buy consumer goods for their own reproduction.

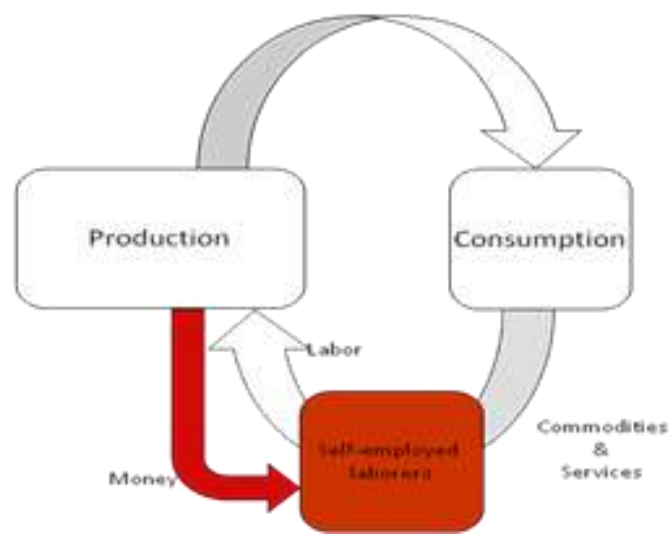

Figure 2: Feedback representation of physical reproduction

\section{Competitive Capitalism}

The third layer in figure 1 brings capitalists into the picture. A second feedback-loop is created (see figure 3). Part of the wealth created by workers is now directed to capitalists. The (former) self-employed producers become now workers and earn wages or salaries. They have access to income only by way of the labour market, which brought a qualitative change compared to layer 2 .

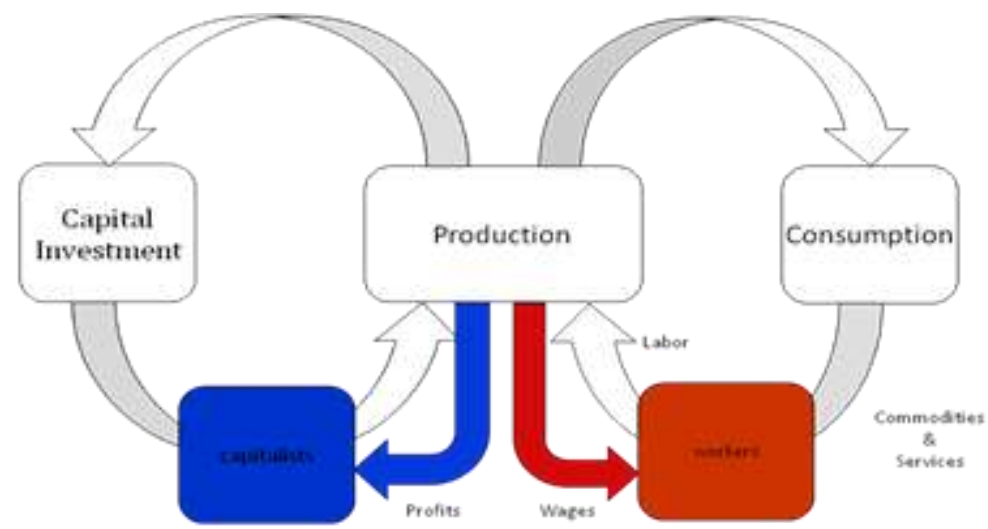

Figure 3: Two feedback loops: Capitalists and Workers 
The second feedback-loop (left side) in figure 3 is qualitatively different from the first one. While consumption of workers depends mainly on the levels technology and distribution of wealth have reached, capitalists are in a position to increase their capital by accumulation. Marxists call the groups represented here classes. They speak of exploitation of the workers by capitalists, because capitalists as owners of the means of production pay workers and employees a wage, which is less than the value of the products workers create.

\section{Finance Capitalism}

In the beginning of the 20th century capitalist development reached a new level which was not foreseen by Marx and Engels. The basis for this change was the second revolution of the productive forces, "the electrotechnical revolution", as the German historian Jürgen Kuczynski has called it. ${ }^{4}$ Large scale investment in a new kind of technology led to higher concentration (growth of individual capital) and centralisation (various individual capitals become united) of capital. The Vienna born economist Rudolf Hilferding called this kind of capital "Finance Capital" (Finanzkapital). Hilferding wrote 1910:

"The dependence of industry on the banks is therefore a consequence of property relationships. An everincreasing part of the capital of industry does not belong to the industrialists who use it. They are able to dispose over capital only through the banks, which represent the owners. On the other side, the banks have to invest an ever-increasing part of their capital in industry and in this way they become to a greater and greater extent industrial capitalists. I call bank capital, that is, capital in money form, which is actually transformed in this way into industrial capital, finance capital. "'5

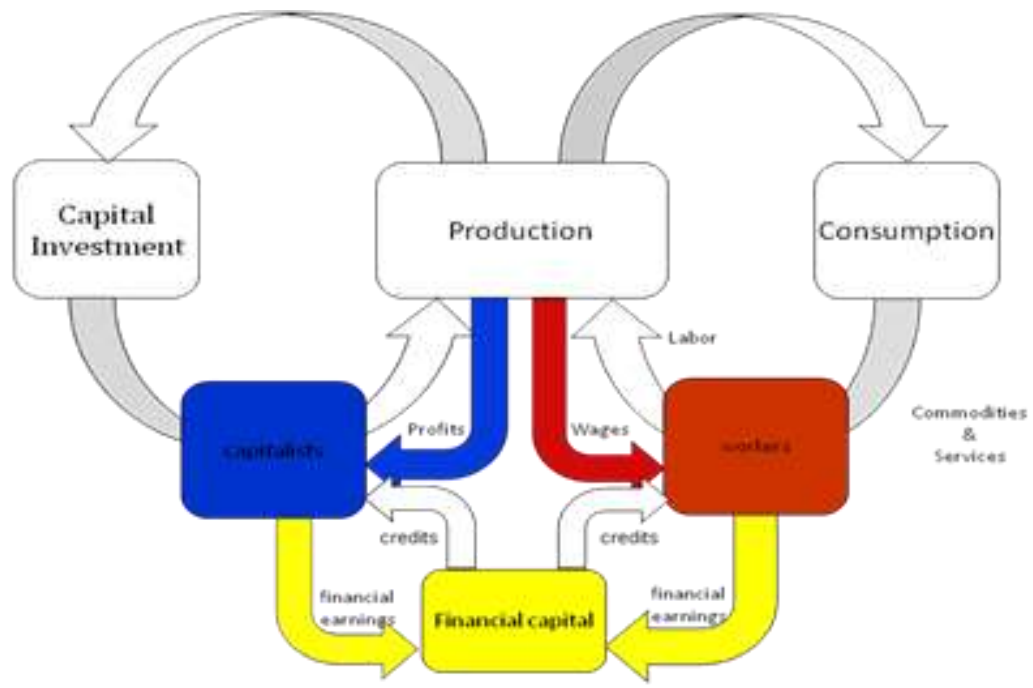

Figure 4: Finance Capitalism

Finance capital represents the fusion of the capitals of banks and industries on the one hand; on the other it is an indication of the degree of control of the production process and on the degree of centralisation and concentration by banks. Under the hegemony of finance capital industrial capitalism transformed into finance capitalism (see fig. 1, layer 4, and fig 4.). This development meant socialization (Vergesellschaftung) of a certain degree, not for the whole society, but restricted to capital owners.

There remains the question if the private way of financing by capitalists was the only one. A new way of financing could have been found. From a system's theoretic point of view such moments in history can be seen

4 Busch, Ulrich: Geldkapital, Finanzkapital und Finanzindustrie. 104-117.

5 Hilferding, Rudolf: Das Finanzkapital. 283. 
as branching points for future development. More than one option for further evolution becomes possible. The future opens up. The opportunities of change increase considerably. Hilferding favoured a new kind of dominance, not by oligarchy, but by the masses of the proletariat:

"The tendency of finance capital is to establish social control of production, but it is an antagonistic form of socialization, since the control of social production remains vested in an oligarchy. The struggle to dispossess this oligarchy constitutes the ultimate phase of the class struggle between bourgeoisie and proletariat."6

At that time this option did not become reality. But were there also other opportunities of financing? I think, in principle yes, but the probability for it was very low. Capital could have been also been collected from the working masses, not from banks or wealthy capitalists. This could have led the development into a different direction.

\section{State Monopoly Capitalism and its Alternatives}

During the first decades of the $20^{\text {th }}$ century a qualitative change of the capitalist system began with the new role of the state. Already in the middle of the $19^{\text {th }}$ century saw Marx and Engels in the Communist Manifesto the state as an instrument of the capitalist class: "The executive of the modern state is but a committee for managing the common affairs of the whole bourgeoisie." But at the same moment they identified an opportunity for change by changing its content. To initiate a change of the system they requested the working class to conquer the state. After the state has changed its capitalist character it would be possible to start with a communist society: ".....the first step in the revolution by the working class is to raise the proletariat to the position of ruling class to win the battle of democracy... The proletariat will use its political supremacy ... to centralise all instruments of production in the hands of the State."

But it is still a debated question what kind of state they had in mind. In their 1850 „Address of the Central Committee to the Communist League" Marx and Engels described its organisational form in more detail:

"Alongside the new official governments they must simultaneously establish their own revolutionary workers' governments, either in the form of local executive committees and councils or through workers' clubs or committees, so that the bourgeois-democratic governments not only immediately lost the support of the workers but find themselves from the very beginning supervised and threatened by authorities behind which stand the whole mass of the workers. "8

The ideas of Marx and Engels to transform the state by a revolution had to wait for Lenin. He did a lot of theoretical work before he could succeed. In 1917 he coined the term „state monopoly capitalism", indicating that the state plays a more important role in the economy (see fig.1, layer 5), in particular for waging wars:

"Monopoly capitalism is developing into state monopoly capitalism. In a number of countries regulation of production and distribution by society is being introduced by force of circumstances. "I

Referring to Engels Lenin had the idea that the bourgeois state has already started organizing production according to plan contrasting the anarchy of production in early capitalism. Lenin had in mind that the more the capitalist state is able to coordinate the economy, the more mature this type of capitalism will be for a

6 op. cit.

7 http://www.marxists.org/archive/marx/works/1848/communist-manifesto/ch01.htm

8 http://www.marxists.org/archive/marx/works/1847/communist-league/1850-ad1.htm

9 Lenin, Vladimir Iljitsch: Speech in favour oft the resolution on the current situation April 29 (May 12).

http://www.marx2mao.com/PDFs/Lenin\%20CW-Vol.\%2024.pdf p. 305 
transition to socialism. Looking back we know that Lenin tried to establish a new regime with the slogan:

"Communism - that is Soviet power plus electrification of the whole country".

But after Lenin's death state bureaucracy in the Soviet Union was not transformed to meet the interests of the proletarian masses with highest priority but merged with Stalin's autocratic interests. The state did not promote the interests of capitalists any longer, but the interests of a new oligarchy of the "nomenclature". Some researchers characterized the socialist countries in hindsight as a "state-dictatorship" or a "party-dictatorship". Not to repeat such negative developments, one should learn for the future that any bureaucracy has to be institutionally controlled by the people as directly as possible.

In contrast to the socialist scenario of the state in Russia the German state was occupied by the National Socialists who have also exploited the opportunity to change its content. WWII with more than 64 million deaths and the holocaust were the terrible consequences. Starting with January 1933 when Hitler became Reichkanzler the Nazis created a fascist dictatorship guided by the "Führer"principle. With the attack on Poland 1939 they started a war of conquest developing into a world war. Six million Jews were murdered, 500.000 Sinti and Roma, countless members of ethnic minorities and political opponents were executed. While the Soviets transformed large scale enterprises and private property in agricultural production into state or community property, under fascism the capitalist structure of the economy remained in place.

The transformation processes around the state did not come to an end yet. Even today the majority of democratic states with capitalist economies are permanently under the danger of being undermined by authoritarian tendencies, even more so in times of economic crisis.

\section{Finance Market Capitalism driven by Information Society}

Since the beginning of the scientific-technical revolution around the middle of the 20th century the productive forces took a new direction. The mechanisation trend of the industrial revolution was complemented by automation. This became possible by the invention of a new technical device, the "information processing machinery" ${ }^{10}$. While the "working machine" characterized the industrial revolution, ${ }^{11}$ automation was the result of the interaction of the working machine and the information processing machinery.

10 Adler, Frank: Zu einigen Grundmerkmalen der wissenschaftlich-technischen Revolution. 13.

11 "All fully developed machinery consists of three essentially different parts, the motor mechanism, the transmitting mechanism, and finally the tool or working machine. The motor mechanism is that which puts the whole in motion. It either generates its own motive power, like the steam-engine, the caloric engine, the electromagnetic machine, \&c., or it receives its impulse from some already existing natural force, like the water-wheel from a head of water, the wind-mill from wind, \&c. The transmitting mechanism, composed of flywheels, shafting, toothed wheels, pullies, straps, ropes, bands, pinions, and gearing of the most varied kinds, regulates the motion, changes its form. where necessary, as for instance, from linear to circular, and divides and distributes it among the working machines. These two first parts of the whole mechanism are there, solely for putting the working machines in motion, by means of which motion the subject of labour is seized upon and modified as desired. The tool or working machine is that part of the machinery with which the industrial revolution of the 18th century started." Marx, Karl: Das Kapital. Vol 1, Chapter 15.

http://www.marxists.org/archive/marx/works/1867-c1/ch15.htm\#S1 


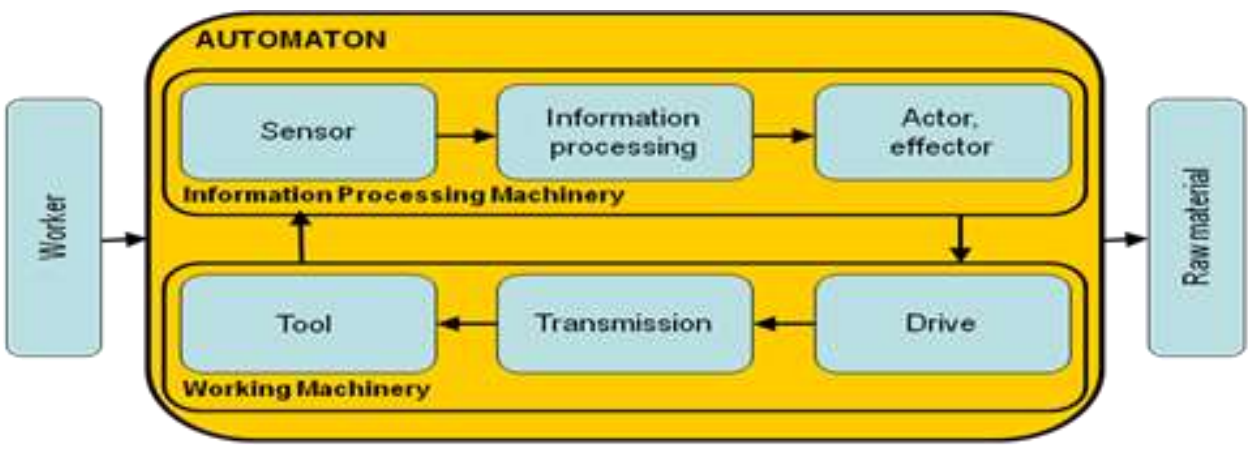

Figure 5: Basic scheme of the Automaton - the interaction of working machinery and information processing machinery

During the last fifty years the information processing machinery spread world wide as stand-alone machinery (e.g. pocket computer, personal computer, laptop, tablet etc.). More recently, it was interconnected via electronic networks. The expansion of Internet and mobile communication has allowed for a tremendous reduction of transaction costs. The creation, distribution, diffusion, use, integration and manipulation of information, and - as a consequence - decision making, communication, administration and organisation has become much cheaper than before. As a response the number of users of the Internet and of mobile phones grew exponentially and provided a new basis for doing business globally. In particular, neoliberal globalization with the growing importance of financial capital and financial markets would not have been possible without these new gadgets. The German economist Ulrich Busch speaks therefore of a new development of finance capitalism, "finance market capitalism" ("Finanzmarktkapitalismus", see fig. 1, layer 6). ${ }^{12}$ Since the 1980ies finance capitalism, which Hilferding had observed, increased its importance and its power by new institutions and also its range. It is no longer restricted to a single country, it forms an international network. The contemporary finance industry consist not only of banks, but also of insurance companies, private pension funding, and all the activities auxiliary to financial services and insurance including funds and fund management, holding companies and rating agencies. ${ }^{13}$

A recent study ${ }^{14}$ analysed the control relationship between the companies on a global level. They used a database with "about 37 million economic actors, both physical persons and firms located in 194 countries, and roughly 13 million directed and weighted ownership links (equity relations)". They focussed on transnational companies (TNCs) and identified "a list of 43060 TNCs located in 116 different countries, with 5675 TNCs quoted in stock markets." 15 They looked for the degree of control companies exerted on others. Finally they identified 50 companies controlling $40 \%$ of the global value of firms. All fifty are part of the finance industry or very close to it. None of them is a classical production company.

Seen from an economic point of view information society as it is now is a society mainly controlled by finance market capitalism, acting on a global basis. As we can learn from the public debt crisis in Euroland the nation state is increasingly under the threat of blackmail by rating agencies. It is not impossible that Euroland will break apart. But there is also a politically different perspective, as we will describe in the following.

12 Busch, Ulrich: Geldkapital, Finanzkapital und Finanzindustrie. 113.

13 The financial industry consists of the code numbers starting with 65,66 and 67 . The code numbers 7414 (Business and management consultancy activities) and 7415 (Management activities of holding companies) can be seen as very close to the finance industry. For a complete list of the 2006 NACE code of the European Union, see http://www.ellispub.com/eclo/help/nacecodes_old.htm

14 Stefania Vitali, James B. Glattfelder, Stefano Battiston, The Network of Global Corporate Control. http://www.plosone.org/article/info\%3Adoi\%2F10.1371\%2Fjournal.pone.0025995;

15 http://www.biomedsearch.com/attachments/00/22/04/62/22046252/pone.0025995.s001.pdf, 3. 


\section{A democratic turn?}

Information technologies are not only a playground for enterprises. While the workers are controlled at their electronic workplaces and citizens are surveyed by video cameras at many corners of the streets, information technology shows also a large democratic potential. Falling transaction costs do not only mean an advantage for enterprises, but also for the citizen. Groups of people can cheaply exchange their opinion, they can publish information blocked by other media, they can invite for manifestations (maybe faster than the police can check). We see the bloggers are able to influence public opinion; even proposals for Laws on intellectual property rights (ACTA) could not be passed because of electronic opposition. Wikileaks played an important role to increase public awareness and added transparency to unpublished state activities. Denial of service attacks brings flourishing firms into difficulties. In short, there is increasing potential for opposition as we already could see in the Arab Spring (or Arab Revolution) at the end of 2010, a revolutionary wave of demonstrations, protests and civil uprisings in some states of northern Africa and Middle East Frequently protesters shared techniques of civil resistance, often supported by electronic media, for that reason frequently called social media. Although we should not overestimate their role e-mail, Facebook, Twitter, YouTube and blogs have played in the dramatic events - revolutionary conscience and resistance are the most important preconditions - organising meetings and manifestations by electronic means is helpful. Movements like Occupy Wall Street, Indignados, and manifestations in the capitals of Europe are impressive examples of the use of electronic media. It is not impossible that with the help of these social media new political players come into being, strengthening non-governmental organisations and bottom-up initiatives. For the moment, the resistance is limited to protests against existing political measures. New concepts transforming society, economy and culture and new institutions to exert power in a democratic way are still missing. But one should be optimistic: the financial crisis will increase the pressure to generate innovative activities.

\section{Concluding remarks}

To summarize the main ideas of this paper: New technological or institutional developments emerge from existing structures in society. They form new layers on top of the economy and open up new political and economic opportunities, particularly through new types of dominating interests and kinds of property (see figure 6). In history we have seen that the content of the new layer tends to dominate all the former ones.

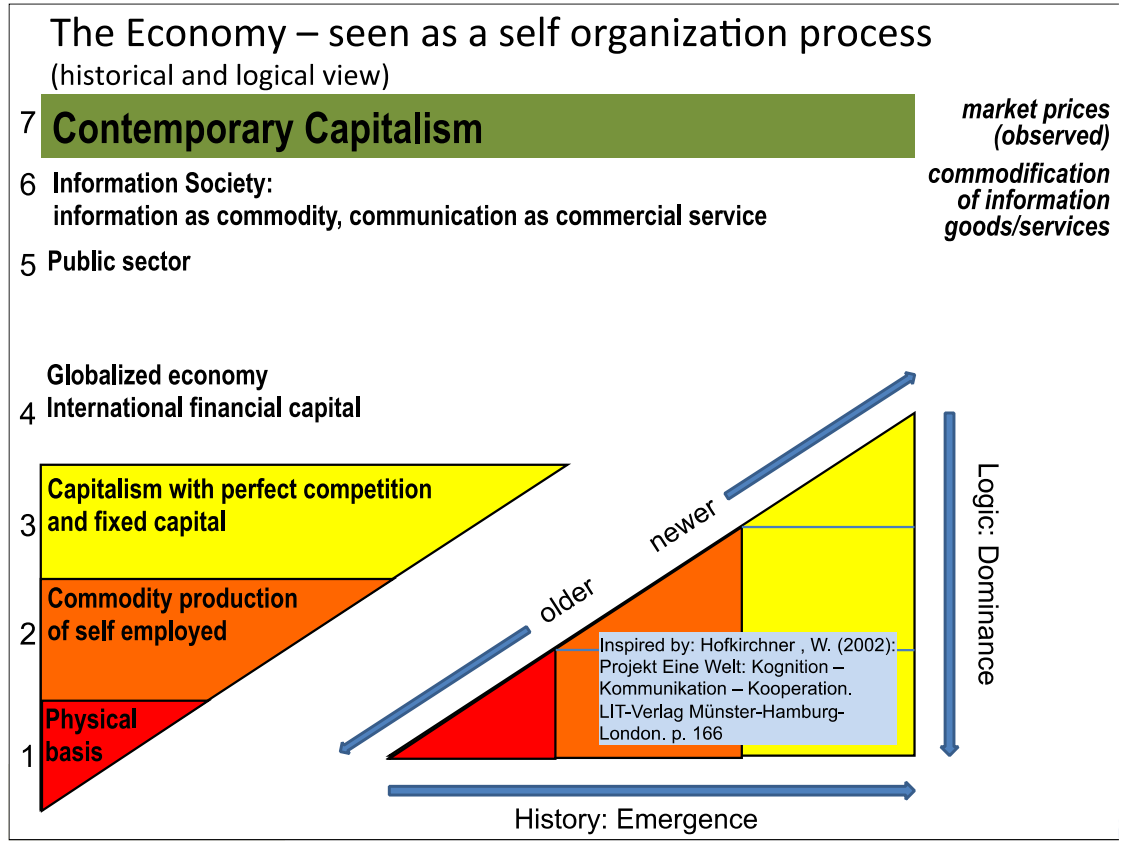

Figure 6: Emergence and dominance in the economic transformation process 
My claim is that economists and other social scientists should actively search for such developments and elaborate possible branching points of development. This will give them the opportunity in their scholarly work to go beyond the past. And they need not stop in the present. They have the possibility also to address the future. The scholars could assess potential pathways and trajectories e and feed their results back to the public. This could enable a new interaction of scientist with other groups of society.

A new type of economy should be socially and environmentally sustainable. It should restore the mutuality which is hidden behind the value concept and should bring into practice that our survival will finally depend on cooperation and not on competition.

\section{References}

Adler, Frank (1978): Zu einigen Grundmerkmalen der wissenschaftlich-technischen Revolution. Wien: Arbeitskreis Wissenschaftlich Technische Intelligenz 1978. 13.

Busch, Ulrich: Geldkapital, Finanzkapital und Finanzindustrie. In: Berliner Debatte Initial 2 2012. 104-117, 113.

Farjoun, Emmanuel, and Moshé Machover: Laws of Chaos: a probabilistic approach to political economy. London: Verso 1983.

Hilferding, Rudolf: Das Finanzkapital, quoted after the Berlin: 1910, reprint 1955 by Dietz Verlag. 283. See the English version at http://www.marxists.org/archive/hilferding/1910/finkap/ch14.htm

Marx, Karl: Das Kapital, Vol 1, Berlin: Dietz 1967. MEW 23. Chapter 15

Marx, Karl and Friedrich Engels: Zur Kritik der Politischen Ökonomie" [Rezension]. MEW 13. Berlin: Dietz 1990. pp. 468-477, 474/475. 